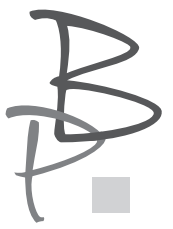

\author{
Bartłomiej Borek* \\ Uniwersytet Marii Curie-Skłodowskiej w Lublinie \\ https://orcid.org/ 0000-0002-7503-8703
}

\title{
„Wieczny mnie rodzi ogień i wyznaję słońce". Żywioł ognia w liryce Wincentego Korab-Brzozowskiego
}

"Eternal fire gives me birth and I confess the sun". The element of fire in poetry by Wincenty Korab-Brzozowski's

Abstract: The article is an attempt to analyze and interpret selected works of Wincenty Korab-Brzozowski, each related to one another by the presence of the element of fire. Referring to the recognition of ancient philosophers, attempts were made to point out the similarities and differences in the treatment of the phenomenon of fire in the author's lyrical work Amongst the stars.

Keywords: Wincenty Korab-Brzozowski's, poetry, fire, life, philosophy.

Bartłomiej Borek - mgr, doktorant literaturoznawstwa na Wydziale Humanistycznym Uniwersytetu Marii Curie-Skłodowskiej w Lublinie. Autor licznych artykułów naukowych, w tym: Kanibalistyczna uczta. O wszechcierpieniu natury w «Niedokonanym» Tadeusza Micińskiego (2018). 
Jak gnie żelazo w ogniu dłoń kowala Wcielając w piękno myśl mu drogą, Jak się bez ognia złotnicy nie mogą Obejść, co słoto im wydoskonala Jak się jedyny Feniks wprzódy spala, By się odrodzić $[\ldots]^{1}$

\section{Wprowadzenie}

Ogień, jak wszystkie z żywiołów, manifestuje się w wieloraki sposób - od blasku słońca, światła błyskawicy, pożaru, przez wybuch wulkanu. Mimo że przejawia się w tak różnorodnych konfiguracjach, nieustannie zachowuje te same, powszechnie rozpoznawalne jakości. Nad nimi właśnie dyskutowano na przestrzeni dziejów, objaśniając w możliwie precyzyjny sposób. Już założenia jońskiej filozofii przyrody sugerowały duże znaczenie żywiołu jako budulca rzeczywistości. O ogniu - tworzywie wszechświata, mówił swego czasu Anaksymander. Określał go mianem apeironu ${ }^{2}$. Podobne zapatrywania przejawiał jego uczeń Anaksymenes. Dla Heraklita „świat jest wiecznie żywym ogniem”3, który, choć równoważy się z morzem i ziemią, ma nad nimi moc władania ${ }^{4}$. Pitagoras, wymieniając składowe żywiołu, poddawał go następującej deskrypcji: ciepły, lekki, suchy, szybki ${ }^{5}$. Dla Empedoklesa, pomysłodawcy czterech pierwiastków 6 , ogień był czymś jaśniejącym. Grecki filozof najprawdopodobniej utożsamiał go z samym Zeusem ${ }^{7}$. Parmenides z kolei, badając naturę eteru, opisywał węższe

1 M. Anioł, Sonet 59, [w:] tegoż, Poezje, przeł., wstęp i przypisy L. Staff, Warszawa-Kraków 1922, s. 222.

2 G. S. Kirk, J. E. Raven, M. Schofield, Filozofia przedsokratejska, przeł. J. Lang, Warszawa-Poznań 1999, s. 138.

3 Cyt. za: tamże, s. 200.

4 Tamże.

5 Zob. G. Reale, Pitagoreizm, [w:] tegoż, Historia filozofii starożytnej, t. I, przeł. E. I. Zieliński, Lublin 2005, s. 105-108.

6 G. S. Kirk, J. E. Raven, M. Schofield, dz. cyt., s. 285.

7 Tamże. 
pierścienie sfer oraz gwiazdy jako pełne „czystego ognia”8. Sam Arystoteles zaś wskazywał na ilościowe cechy żywiołów. W przypadku ognia podkreślił cechy gorąca i suchości, konstatując, że ogień to coś nadmiernie gorącego. Również pozostałe żywioły definiował jako nadmiar cechy podstawowej. Wstępne rozpoznania zbudowano bez wątpienia na przekonaniu, że o naturze żywiołu decydują czyste jakości. Nie bez powodu zresztą. To właśnie one są tymi, które nie dają się oddzielić od fenomenu, gdyż warunkują treść doświadczenia9.

Powszechnie wiadomo, że czyste jakości są nieprzebranym źródłem doznań estetycznych, jak i niewyczerpalnymi rezerwuarami znaczeń naddanych. Żywioły przejawiające się w zjawiskach przyrodniczych potęgują percepcję świata - czynią go atrakcyjniejszym poznawczo. Pierwszy, a zatem podstawowy, kontakt człowieka z żywiołem następuje na drodze sensorycznego doświadczenia. Zdolność zmysłowego odbioru ognia pozwala na wielorakie kategoryzacje. Mimo konkretnych jakości składających się na ów żywioł, jego aktywność w zetknięciu z danym bytem, zdaje się bardziej złożona i różnorodna od innych żywiołów. Ogień buduje, ożywia, scala - jest więc fundamentem życia, ale też: rujnuje, pochłania, spopiela, jednym słowem: niszczy. Jest przecież zjawiskiem, które w zgodzie z zasadą coincidentia oppositorum ${ }^{10}$ funkcjonuje jako spójny w składających się na niego przeciwnościach. Jeśli dany fenomen potrafi zamknąć w sobie przeciwieństwa, można o nim powiedzieć, że przejawia w sobie jakości idealne, może nawet transcendentne. W poezji założenie to przejawia się poprzez znany poetyce zabieg, polegający na sprzeczności w zgodności (discors concordia), który uwydatnia sposób postrzegania żywiołu ognia.

Idealność, harmonijność, atrakcyjność pod względem jakości - wszystko to skłaniało człowieka do tego, by żywioł ognia okiełznać i zrozumieć. Już w przekazach mitograficznych natrafimy na przynajmniej trzy narracje,

8 Tamże, s. 258.

9 Zob. M. Popczyk, Ogień, [w:] Estetyka czterech żywiołów, red. K. Wilkoszewska, Kraków 2002, s. 135 .

10 Coincidentia oppositorum (zlanie/ zjednoczenie przeciwieństw) to idea, o której napisano już wiele. Warto odesłać czytelnika choćby do artykułu Jarosława Frontczaka, który rozpatrywał ten problem w zestawieniu z kulturowym waloryzowaniem przeciwieństw góra-dól, zob. J. Frontczak, Poszukiwanie paradygmatu, „Sztuka i Filozofia” 1996, nr 11, s. 57, 60; zob. też A. Przybysławski, Coincidentia oppositorum, Gdańsk 2004. 
których kanwą okazuje się ów żywioł - projektuje on losy Prometeusza ${ }^{11}$, Hefajstosa oraz Chronosa. W przypadku dwóch pierwszych herosów ogień konotuje - poza jakościami podstawowymi - przede wszystkim wartości kulturotwórcze. Jest zjawiskiem przybliżającym człowieka do znakomitego i bardziej zorganizowanego poznania. Zarówno Prometeusz, jak i Hefajstos posiedli umiejętność ujarzmienia żywiołu, który służył im do kształtowania bytu (obróbka narzędzi choćby) na nowo. Swoje umiejętności i tajemnice opanowania żywiołu przekazali niezbyt jeszcze rozwiniętej ludzkości. Ogień stał się zatem przyczynkiem do rozwoju społeczeństwa w różnych dziedzinach życia. Chronos z kolei, według wierzeń Greków, stworzył ogień wespół z wiatrem i wodą z własnego nasienia ${ }^{12}$. Postaci mitologiczne, dzięki swej złożoności oraz swoistej popularności w dziełach sztuki, są nierzadko wykorzystywane przez artystów jako wysoce funkcjonalne metafory. Liryka młodopolska - której przedstawicielem jest interesujący mnie poeta Wincenty Korab-Brzozowski skupiona na estetycznym aspekcie języka, sięga po liczne wzorce antyczne w celu konstytuowania i prezentowania znaczeń.

Warto jeszcze podkreślić, że przekazany ludzkości żywioł był we wspomnianych narracjach komplementarny. Dar Prometeusza pochodził ze stajni Heliosa, a zatem ulokowany był w przestrzeni niebiańskiej, posiadał więc aktywną moc twórczą. Ogień Hefajstosa wywodził się z kolei z ziemi, desygnowany jako pasywny fenomen chtoniczny - obie formy można zatem utożsamiać z dziedziną sacrum. Zauważmy, że żywioł ten został przez Prometeusza przyniesiony - heros niósł go z nieba na ziemię w trzcinowej gałązce ${ }^{13}$. Przetransportowanie ognia odczytywać można jako swoistą hierofanię, manifestację boskiej mocy i wiedzy na ziemi, a zatem pierwiastek męski. Ogień Hefajstosa to żywioł pozbawiony ruchu, wydobyty z wulkanu nie zmienił swojego miejsca bytowania, nie zyskał nowych jakości, funkcjonuje jako przestrzeń,

11 O Prometeuszu napisano już wiele stron. Aby zapoznać się z jego sylwetką, warto wspomnieć choćby o opracowaniach: C. Rowiński, Prometeusz, [w:] Mit, człowiek, literatura, wstęp S. Stabryła, Warszawa 1992; K. Kerényi, Prometeusz, [w:] tegoż, Misteria Kabirów; Prometeusz, przeł. I. Kania, Warszawa 2000; Ł. Książyk, Maski Prometeusza, [w:] Modernistyczne źródła dwudziestowieczności, red. M. Dąbrowski, A. Z. Makowiecki, Warszawa 2003.

12 G. S. Kirk, J. E. Raven, M. Schofield, dz. cyt., s. 71.

13 Dla Gastona Bachelarda kompleks Prometeusza wiązał się z wiedzą, która przewyższać miała tę ojcowską. 
w której dopiero coś ma powstać, symbolicznie można go zatem odczytywać jako pierwiastek żeński. Oba sposoby rozumienia żywiołów dawały mu zatem moc kulturotwórczą ${ }^{14}$.

Istnieje również przekonanie, iż ogień Hefajstosa funkcjonuje w kulturze jako ten bardziej pragmatyczny, służący człowiekowi do oswojenia codzienności. Ogień z boskiej stajni pełni zaś rolę asumptu na drodze poznania prawdy o sobie i świecie. Wynika z tego, że jest doskonalszy poznawczo. Mimo że żywioły te są różne od siebie semantycznie, jest między nimi pewna paralela - na każdym z nich ciąży także wina kradzieży, zbrodnia przeciw bogom. Na tej podstawie można objaśnić również obciążenie owego żywiołu grozą i niebezpieczeństwem - zdolnościami destrukcyjnymi ${ }^{15}$.

Oczywiście przywołane informacje nie mają za zadanie pełnić osobnego studium, stąd ich skrótowa forma, funkcjonują raczej jako zarys kulturowego zaplecza, nieobcego autorowi Tryumfów, na co wskazuje lektura jego wybranych utworów. Stanowią one niezbędne tło dla badania tekstów Korab-Brzozowskiego, głęboko osadzonych w europejskim dziedzictwie kulturowym.

\section{Ogniste strofy}

Przy próbie całościowego oglądu twórczości autora Wśród gwiazd zauważalna okazuje się przede wszystkim wielotematyczność, skomplikowanie metaforyczne sensów zawartych w utworach (uzyskane choćby wskutek nagromadzenia niejednoznacznych symboli) oraz liczne nawiązania do antyku grecko-rzymskiego i filozoficznych systemów hinduskich. Z pewnością owa różnorodność i niejasność treściowa przyczyniły się w znacznym stopniu do nieporozumień interpretacyjnych i niechęci wobec rzeczonego materiału poetyckiego. Dostrzegał to już przed ponad pięćdziesięciu laty Jacek Trznadel ${ }^{16}$. Od tamtego czasu badania posunęły się nieznacznie.

15 Więcej na temat mitu o Prometeuszu i Hefajstosie zob. G. Bachelard, Filozofia, która mówi nie, przeł. J. Budzyk, Gdańsk 2000; tegoż, Płomień świecy, przeł. J. Rogoziński, Gdańsk 1996; tegoż, Poetyka marzenia, przeł. i oprac. L. Brogowski, Gdańsk 1998; tegoż, Wyobraźnia poetycka, przeł. H. Chudak, A. Tatarkiewicz, Warszawa 1975; M. Głowiński, Ten śmieszny Prometeusz, [w:] tegoż, Mity przebrane. Dionizos, Narcyz, Prometeusz, Marchołt, Labirynt, Kraków 1990; M. Eliade, Kowale i alchemicy, przeł. A. Leder, Warszawa 1993.

16 J. Trznadel, Wincenty Korab-Brzozowski, [w:] Literatura okresu Młodej Polski, t. 1, red. K. Wyka, A. Hutnikiewicz, M. Puchalska, Warszawa 1968, s. 531-547. 
Na spuściznę młodopolskiego poety składa się, co zaskakuje, tylko jeden zbiór. Są nim wydane współcześnie Utwory zebrane (442 s.; na podstawie tomu Dusza mówiąca z 1910 roku) w opracowaniu Mariana Stali. Odnaleźć tu można zarówno poetyckie próby, thumaczenia oraz parafrazy bardziej i mniej znanych dzieł, jak również wspólne utwory Wincentego oraz jego brata - Stanisława.

Rozpoznawanie twórczości literackiej młodopolanina - w której główną rolę odgrywa pojęcie ognia - wymaga nie tylko zbadania sfery niejasnych sensów, ale również opisu językowej organizacji tekstów czy wpływów innych dzieł, z którymi utwory Brzozowskiego tworzą sieć relacji dialogowych.

W lirycznej twórczości Korab-Brzozowskiego ogień pojawia się wyjątkowo często. Sugeruje to zatem, że zajmuje w niej miejsce znaczące. I rzeczywiście tak jest. Mnożące się przykłady obecności ognia generują intrygujące światy. Już w jednym z pierwszych dzieł poety pojawia się ogień i kojarzeni z nim bohaterowie kultury antycznej.

W cyklu Węglem smutku i zgryzoty pojawia się przywoływany już tytan Prometeusz. Pomimo wykorzystania popularnego i właściwie jednoznacznego znaczeniowo motywu prometejskiego w wierszu o incipicie I ciepty jeszcze, purpurowy sznur, Brzozowski projektuje dramatyczne napięcie, przekształcając znaną narrację w zaskakujący sposób:

Więc na toż Ognia zdobyliście łup,

Złodzieje bogów, o Prometeusze?

Oh! niechaj na zawsze wieczysty grób

Pochłonie nasze biedne ludzkie dusze! 17

W zacytowanym passusie odnajdziemy składowe budujące relację o przekazaniu ludzkości ognia. Jednak ów opis ma zaskakująco negatywny wydźwięk. Dlatego też konieczne wydaje się przywołanie reszty wiersza, które do mitu już nie nawiązuje, ale wiele wyjaśnia:

17 W. Korab-Brzozowski, I ciepły jeszcze, purpurowy sznur, [w:] tegoż, Utwory zebrane, oprac. M. Stala, Kraków 1980, s. 84. 
I ciepły jeszcze, purpurowy sznur,

Płynący z łona zranionego słońca,

Sączy się, cicho, po szczelinach gór,

O moje oczy! i już noc bez końca...

Z lękiem się kryje wszelki ziemi twór;

Serc przerażonych zamknęły się wrota -

I pustynia głucha zamieszkała dwór,

I rozpaczliwa w ciemności golgota...

Ludzkość nadużyła zaufania tytana. Otrzymawszy ogień, uczyniła z niego broń, nie zaś narzędzie służące dla dobra ogółu. Próbując odkryć zaszyfrowane przez poetę znaczenia, mamy prawo do dwojakiego potraktowania ognia. Z jednej strony odczytamy jego obecność oczywiście najprościej, bo dosłownie - dostrzeżemy żywioł mogący przyczynić się do polepszenia warunków cywilizacyjnych, z drugiej zaś potraktujemy go jako symbol - symbol wiedzy, wtajemniczenia, doświadczenia i prawdy. Co ciekawe, Brzozowski nie chwali następców swego protoplasty. Prometeusze ${ }^{18}$ są ludźmi wielkimi wyłącznie we własnych oczach. Dlatego też podmiot liryczny z wyrzutem i ironią dopytuje o wartość ich „wielkich” czynów. Niestety, ludzkość nie rozumie znaczenia imienia, które przyszło jej nosić19. Skutkiem niewiedzy będzie oczywiście upadek.

Mit o Prometeuszu, będąc kanwą liryku Brzozowskiego pełni rolę asumptu do rozważań nad tematami aktualnymi. W prototypowym micie o Prometeuszu ${ }^{20}$ czyn przekazania ludziom ognia był niewątpliwie waloryzowany dodatnio, mimo bycia przyczyną cierpień tytułowego herosa. W słowach autora

18 O znaczeniu multiplikacji postaci mitologicznych - jako wskazaniu na współczesną cywilizację - pisał już Marek Kurkiewicz. Por. M. Kurkiewicz, Bohaterowie antycznych mitów w poezji twórców Młodej Polski, [w:] Ateny. Rzym. Bizancjum. Mity Śródziemnomorza w kulturze XIX i XX wieku, red. J. Ławski, K. Korotkich, Białystok 2008, s. 425.

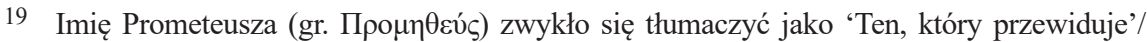
'Przewidujący' bądź 'Myślący w przód'.

20 Najważniejszą z zachowanych do czasów współczesnych wersji mitu o Prometeuszu odnajdziemy w tragedii Ajschylosa Prometeusz skowany. Niestety, nie zachowały się pozostałe części owej trylogii. 
Wśród gwiazd stał się przewrotnie - przyczyną śmierci i braku nadziei. Czyny kolejnych Prometeuszy okryte zostały hańbą. Ogień, co ciekawe, został tu potraktowany jako dar wysączający się ze zranionego bóstwa - Słońca. Dlatego też prawdopodobnie została wyeksponowana górska kolorystyka nieba, szczególnie dostrzegalna podczas wschodów i zachodów, gdy światło nabiera czerwono-złotej, a więc ognistej barwy. Tego rodzaju obrazowanie sugerować ma, że górskie szczyty płoną.

Już ta drobna analiza pozwala poczynić ważne dla nas rozpoznanie, mianowicie, że poeta przywołując w swoich utworach bohaterów mitów, czyni to w sposób dwojaki: albo traktuje ich jako inspiracje złożone, tworzące pełny obraz rzeczywistości grecko-rzymskiej, albo podkreśla obecność tychże postaci poprzez pojedyncze motywy, w rezultacie czego funkcjonują oni na zasadzie symbolu czy też personifikacji konkretnych cech i wartości. Drugie z zaproponowanych przez poetę rozwiązań posiłkowania się przekazem mitycznym obecne okaże się również w Stancach ${ }^{21}$. W tymże cyklu, dość niespodziewanie, wprowadził pisarz kilku mitycznych bohaterów. I choć Stance Brzozowskiego to utwory nader krótkie - każdy z nich liczy sobie raptem pięć wersów - to ich warstwa semantyczna przesiąknięta jest wielością znaczeń. Jednym z utworów poświadczających bogactwo znaczeniowe cyklu jest liryk Doświadczeni ufundowany na kanwie odniesień i przenośni proweniencji antycznej. Co interesujące, przywołane w nim konteksty nie pochodzą z jednego mitu $^{22}$. Poeta świadomie połączył pozornie niemające ze sobą nic wspólnego sytuacje, których znaczenia stają się czytelne dopiero po odszyfrowaniu

21 Stance to miara wiersza o wyrazistej i zamkniętej budowie. Jego długość wahała się od kilku do kilkunastu wersów.

22 Aktualizacja schematów mitograficznych sprzyjała uzyskaniu uniwersalności podejmowanych tematów, służyła też historiozoficznej refleksji (na podstawie twórczości KorabBrzozowskiego wywnioskować można, że najbliższą ideą historiozoficzną był dla niego heroizm - założenie postulujące istnienie świata na fundamencie doniosłych czynów wielkich bohaterów. Za twórcę idei uważa się powszechnie Giambattistę Vico). Erudycyjny związek autora Domus aurea z klasyką literatury światowej poświadcza nie tylko wprawa w posługiwaniu się aluzjami do dzieł Homera, Wergiliusza czy Hezjoda, ale przede wszystkim umiejętność scalania w obrębie wypowiedzi lirycznej wielu mitologicznych symboli i znaków, prowadząca do powstania polimitycznych konstrukcji znaczeniowych (Jarosław Ławski określa taki proces supra-morfozą mitów, więcej na ten temat zob. J. Ławski, ,Ukrzyżowanie Prometeusza”. Przemiany mitu w „,Xiędzu Fauście” Tadeusza Micińskiego, [w:] Ateny. Rzym. Bizancjum ..., s. 722). 
wszystkich pojedynczych znaczeń - z tego właśnie powodu słuszne wydaje się przekonanie, że czytelnik, dzieł urodzonego w Syrii poety, winien znać kulturowy kod antyku:

\author{
Próżne nam były Kasandry wołania, \\ I oto - Styksu groźne przed nami koliska. \\ Czy jednak już nie bliski cudu zmartwychwstania \\ Feniks nowy z popiołów tego cmentarzyska? \\ O, nieszczęśni! nauczcie się sztuki czekania²3.
}

Liryk został skonstruowany na planie trzech metafor: wołania Kasandry; groźnych kolisk Styksu oraz ponownych narodzin Feniksa z popiołów. Przez wzgląd na temat szkicu pomijamy omówienie dwóch pierwszy metafor, niemających pozornie zbyt wiele wspólnego z ogniem ${ }^{24}$. Najważniejsza jest oczywiście metafora mitycznego ptaka, który ulegając samospaleniu, odradza się z popiołów.

Jak pokazują ostatnie wersy liryku, może jeszcze nastąpić - co znaczące w kontekście obecnego w literaturze Młodej Polski synkretyzmu religijnego ${ }^{25}$ - zmartwychwstanie:

Czy jednak już nie bliski cudu zmartwychwstania

Feniks nowy z popiołów tego cmentarzyska?

0, nieszczęśni! nauczcie się sztuki czekania.

23 W. Korab-Brzozowski, Doświadczeni, [w:] tegoż, Utwory zebrane, s. 223.

24 Więcej na temat pominiętych tu analiz metafor przeczytać można w innym moim artykule: B. Borek, „Próżne nam były Kasandry wołania”. O wybranych inspiracjach antykiem w twórczości Wincentego Korab-Brzozowskiego, „Studia Ełckie” 2019, nr 2, s. 275-292. Należy jednak nadmienić, że w kontekście ognia pierwsze dwie metafory mają z nim wiele wspólnego, niemniej poeta o tym nie wspomniał, dlatego ich nie omawiamy. Pamiętamy przecież, że w wizjach Kasandry Troja płonęła. Gdyby Styks traktował Brzozowski metonimicznie jako ogół rzek płynących przez Hades, to może istotny okaże się fakt, że jedną z tych rzek (a konkretnie Flegeton) była nazywana „rzeką ognistą”.

25 Podobną tezę o potrzebie zuniwersalizowania religii zdawał się stawiać swego czasu także Eduard Schuré w swym najgłośniejszym dziele, wielce intrygującym dla metafizycznych poetów Młodej Polski, dla których idea Boga i sacrum była jednym z najważniejszych motywów ich poetyckich aktywności. Por. E. Schuré, Wielcy wtajemniczeni. Zarys tajemniczych dziejów religii, przeł. W. Nidecka, Warszawa 1926, s. 523. 
Cywilizacja, utożsamiona tu z mitycznym Feniksem ${ }^{26}$, ma prawo do apokatastazy - odnowienia wszechrzeczy ${ }^{27}$. Prawdopodobnie pobrzmiewają tu echa stoicyzmu, zobrazowana została przecież idea cyklów odrodzeń - teoria wielkiego pożaru świata, sugerująca, że najwyższy byt niszczy świat przez kataklizmy, by następnie schorowany mógł się odnowić, roztopić w praogniu ${ }^{28}$. Przed nowonarodzeniem musi cierpieć, cywilizację czeka spalenie, podeptanie i znieważenie, odrodzenie z prochów to kwestia przyszłości. Zmartwychwstanie okaże się możliwe dopiero po zdobyciu lekceważonej do tej pory umiejętności „sztuki czekania”.

Warto nadmienić, że o ogniu i odnowieniu wszechrzeczy pisał swego czasu także Tadeusz Miciński w poemacie Niedokonany. Ogień i światło Korab-Brzozowskiego jest zasadniczo różne od przedstawienia z najgłośniejszego dzieła autora Nietoty. W nim to poeta pisał o ogniu jako żywiole harmonizującym z mrokiem i katastrofą 29 . Odmienne waloryzowanie żywiołu sytuuje Korab-Brzozowskiego w gronie poetów klasycyzujących, dla których ogień był najpojemniejszym semantycznie z żywiołów, dlatego, obok wody, pojawiał się najczęściej.

Niemal w każdym z wierszy poety, traktującym o ogniu, prócz słońca pojawia się jakieś określone źródło światła: gwiazdy, ogień, księżyc czy wulkan. Rzadziej uobecnia się opalescencyjna ${ }^{30}$ aktywność kamieni szlachetnych ${ }^{31}$. Mimo że źródeł światła jest wiele, najważniejsze okazuje się jego pochodzenie

26 Korab-Brzozowski kilkakrotnie przywoła jeszcze postać feniksa (m.in. w drugim wierszu cyklu Spotkanie), niemniej tylko w prezentowanej eksplikacji owy ptak przyjmuje tak znaczącą semantykę.

27 Słuszne wydaje się tu powołanie na motyw starożytnej apokatastazy, obecnej zarówno w świecie pogańskim, jak i chrześcijańskim. Por. W. Myszor, Orygenes jako systematyk, [w:] Orygenes, O zasadach, przeł. S. Kalinkowski, Warszawa 1979, s. 25; H. Pietras, Poczatki teologii kościoła, Kraków 2007, s. 335-346.

28 Zob. W. Szczerba, Kosmiczna koncepcja wiecznego powrotu w filozofii starej Stoi, „Theologica Wratislaviensia” 2007, t. 2, s. 20.

29 Zob. J. Ławski, Wyobraźnia lucyferyczna. Szkice o poemacie Tadeusza Micińskiego „Niedokonany, kuszenie Chrystusa Pana na pustyni”, Białystok 1995, s. 95. Ławski zauważa, że ogień powiązany jest bezpośrednio ze światłem, ale w dziele Micińskiego nie emanuje on światła, jest raczej symbolem męki piekielnej, czystego cierpienia.

30 Opalescencja to zdolność niektórych minerałów do iryzacji (tęczowania) - odbijania światła i mienienia najróżniejszymi barwami.

31 Szczególnie widoczna jest ona w poemacie prozą Wśród gwiazd, w którym to kamienie szlachetne funkcjonują na zasadzie gwiazd. 
naturalne - Słońce. W cyklu Domus aurea staje się ono źródłem wszechrzeczy: „Wieczny mnie rodzi Ogień i wyznaję Słońce”32.

Nie ma wątpliwości, że bohater poezji Korab-Brzozowskiego jest jakimś tajemniczym piewcą i wojownikiem Słońca ${ }^{33}$. Najdobitniej uwidacznia się to w VI wierszu owego cyklu:

Śpiewajmy Ognia Świętego objawy,

Od których życie, wiedza, moc powstała:

Słońce i Gwiazdy i Księżyc złotawy -

Wieczna im chwała! ${ }^{34}$

Ukazane we fragmencie światło pełni rolę metafory najwyższej siły, potęgi i tajemnicy istnienia - źródła wszystkiego, co istnieje. To wyraz radości życia. Bohater dzieła pragnie owe szczęście posiąść. Czci Słońce, ponieważ przeczuwa konieczność zrozumienia sensu istnienia. Nie cofnie się przed poznaniem go, nawet jeśli będzie musiał się poświęcić, by osiągnąć upragniony cel. Warto też podkreślić, że poeta stosując paralelizm składniowy, wskazuje na funkcje poszczególnych ciał niebieskich. Słońce to życie, co wpisuje się w jego kulturową funkcję, gwiazdy to moc charakterystyczna dla bóstw lunarnych, jak i pierwszego okresu istnienia ludzkości. Pierwszej fazie istnienia patronuje przede wszystkim Księżyc - to on daje moc wzrastania, rozmnażania się, patronuje rośnięciu w siłę.

Kluczową składową świata przedstawionego cyklu autora W'́ród gwiazd jest niewątpliwie Słońce. Co ważne, zdaje się ono pełnić funkcję analogonu względem posągu Nerona-Heliosa, będącego centrum Złotego pałacu ${ }^{35}$, którego

32 W. Korab-Brzozowski, Domus aurea IV, [w:] tegoż, Utwory zebrane, s. 41.

33 O motywach solarnych w literaturze młodopolskiej pisał swego czasu Jerzy Kwiatkowski w rozprawie Od katastrofizmu solarnego do synów stońca, [w:] Młodopolski świat wyobraźni, red. M. Podraza-Kwiatkowska, Kraków 1977, s. 231-325. Niemniej autor rozprawy o obecności solaryzmu w liryce Korab-Brzozowskiego napisał zaskakująco niewiele. Wymienił trzy utwory z omawianego tu cyklu (IV, V, IX) bez szerszego ich omówienia. A szkoda, gdyż ów rozdział świadczy o ogromnej erudycyjności badacza. Niestety nie dowiemy się, co na temat cyklu myślał Kwiatkowski.

34 W. Korab-Brzozowski, Domus aurea VI, [w:] tegoż, Utwory zebrane, s. 43.

35 Warto odnotować, że w podziemiach tego pałacu znaleziono groteskowe, karnawałowe malowidła, które zadziwiły renesansowych badaczy. Ich odkrycie rzuciło nowe światło na starożytnych, postrzeganych do tej pory jako zwolenników harmonii i porządku w sztuce. 
łacińska nazwa jest tożsama z omawianym cyklem. To wokół potęgi, jaką jest Słońce, konstytuuje się życie. Poeta z emfazą przekonuje, że wszystko rodzi się w płomieniach.

Intrygujący ze względu na niebanalne operowanie słoneczną metaforą okazuje się też inny wiersz cyklu, w którym główną rolę odgrywa ontologiczna odmiana przenośni:

Słów mych uderzę w was słonecznym grotem

I śpiewać będę z anielskim wzruszeniem:

Cieszmy się! Dusza jest wewnątrz Płomieniem,

A zewnątrz - Lotem! ${ }^{36}$

Ten drobny czterowiersz tylko z pozoru wydaje się niewymagający intelektualnego wysiłku na poziomie odszyfrowywania sensów. Poza modelowym dla cyklu posługiwaniem się motywami solarnymi, odniesieniami do topiki chrześcijańskiej, ujawnia się także nawiązanie do myśli żydowskiej, w której to dusza określana była z hebr. ruah - tchnieniem, wiatrem, twórczym ogniem. Poeta pisze jakby świadomie i zgodnie z Heraklitowym przekonaniem, iż dusza to ogien' ${ }^{37}$. W liryku Korab-Brzozowskiego byt ten funkcjonuje jako coś złożonego, budowa duszy jest dualna ${ }^{38}$ - ma swoje zewnętrze - któremu odpowiadają: powietrze, $\operatorname{lot}^{39}$, tchnienie, a także wnętrze - utożsamiane $\mathrm{z}$ ogniem, płomieniem. Słowa - będąc jednym ze słów-kluczy potrzebnych do zrozumienia tej poezji - którymi operuje poeta, nie są czymś możliwym do percypowania zmysłem słuchu, funkcjonują one na zasadzie grotów strzał, którymi

36 W. Korab-Brzozowski, Domus aurea II, [w:] tegoż, Utwory zebrane, s. 39.

37 Stownik myśli filozoficznej, red. M. Kuziak, S. Rzepczyński i in., Bielsko-Biała 2004, s. 24.

38 Dorota Filar w jednym ze swych szkiców przypomniała stałą w kulturze zasadę o dualności człowieka, który składa się z duszy i ciała, zatem z tego, co „wewnątrz” i na „zewnątrz”. Wykorzystując tę prawidłowość, analizowała wybrane utwory współczesnych poetów, wskazując na funkcjonowanie w nich metafory pojemnika. Zob. D. Filar, Poetyckie kreacje cielesności w wybranych utworach poezji wspótczesnej, [w:] Kreowanie świata w tekstach, red. A. M. Lewicki, R. Tokarski, Lublin 1995, s. 105-106.

39 Motyw lotu odnajdziemy jeszcze w Domus aurea X. Niebiosa znowu zostają tu potraktowane jako księga wyroków warunkujących losy Ziemian - poeta widzi w niej rozpisaną własną duszę, którą nieustannie wiąże z ogniem, pisząc o niej jako o „ognistym rapsodzie”. Wyższe poznanie zostało zobrazowane za pomocą wyrażenia „lotu” i ,jazdy”. Wyraz ,jazda” został tu oczywiście użyty w swym archaicznym znaczeniu (wyprawa, podróż, wypad). 
człowiek, co przekonująco wybrzmiewa w metaforze językowej ,słowa mogą ranić”, może walczyć. Słuszne wydaje się przekonanie, że motyw słów/Słowa odgrywa w owym cyklu rolę performatywną. Zostaje to uwydatnione w jeszcze innej metaforze językowej pojawiającej się w Domus aurea VIII. W nim to właśnie głowa podmiotu lirycznego, utożsamianego z poetą, „płonie głodem wielkich zdarzeń" - trawi go zatem chęć do poetyckiego i bohaterskiego działania.

Podmiot działań twórczych, porzucając już ziemski „hałas”, określany mianem ,próżnego”, zaczyna słyszeć głos Boga, o którym czytamy w Domus aurea I. Należy zauważyć, że wszystkie kolejne wiersze tego cyklu wydają się rozwinięciem motywów rozpoczętych w utworze otwierającym. Pojawiają się i Feniks, i burza, i popiół, i gwiazdy, i księżyc, i noc - wszystko, co składa się na przestrzeń sacrum.

Doświadczający prawdy o świecie bohater kosmicznej wędrówki cyklu Domus aurea głosi:

\begin{abstract}
Wieczny mnie rodzi Ogień i wyznaję Słońce:
W świątyniach jego Wschodu odprawiam obrzędy

Piękne, jak ziemia moja, gdzie kwieciste grzędy

I drzewa są sezamem owoców płonące ${ }^{40}$.
\end{abstract}

Przytoczone słowa kreują kosmiczną metaforę wielkiego rodzenia. Ogień, wbrew swej pierwotnie postrzeganej sile niszczenia w liryku Korab-Brzozowskiego okazuje się dawcą życia ${ }^{41}$. Predykat „rodzi”, wskazuje, co znaczące, na transgraniczne możliwości tego, bądź co bądź, męskiego żywiołu. Ogień jest żywiołem dokonującym wyłomu w utrwalonym od pradziejów porządku natury. To żywioł nadzmysłowy, pozarozumowy, a jednocześnie na tyle bliski człowiekowi, że ten odprawia na jego cześć etycznie i estetycznie najdoskonalsze rytuały. Wielbienie ognia i Słońca jest niezakłócone niedoskonałością świata,

40 W. Korab-Brzozowski, Domus aurea IV, [w:] tegoż, Utwory zebrane, s. 41.

41 I tu ważne okazują się słowa samego Heraklita, który przekonywał: „Ogień żyje śmiercią ziemi, śmiercią ognia powietrze, woda śmiercią powietrza, śmiercią wody ziemia". Przemiany w naturze dokonują się wedle prawidłowości: życie kosztem śmierci. Heraklit, [w:] Filozofia starożytnej Grecji i Rzymu. Wybór tekstów, wybór i wstęp J. Legowicz, przeł. B. Kupis, Warszawa 1970, s. 76. 
w którym owe misterium się rozgrywa. Podmiot liryczny wiersza wypełnia świat ogniem. Metafora skąpanej w ogniu flory nie sugeruje jednak zniszczenia, wręcz przeciwnie, maluje obraz wyłaniania się świata z płomieni, a to zdaje się nawiązaniem do przywoływanego już cyklu odrodzeń. Stoicy byli zwolennikami teorii pożaru świata, a ten bez wątpienia ukonstytuowany został właśnie w cyklu Domus aurea, którego naczelnym twórcą staje się ogniste bóstwo.

Innym utworem, w którym poeta rozważa nad ludzkim życiem w zestawieniu z ogniem, jest liryk o osobliwym tytule Sic transit ${ }^{42}$ :

Życie moje - to odblask daleki...

Daleki odblask płomienia,

Co pewnego poranku zajaśniał - przed wieki, I pewnego wieczoru zagaśnie - na wieki

W tajni Istnienia ${ }^{43}$.

Bohater dzieła to nie tylko piewca siły ognia, ale także dokładny obserwator świata obdarzony czuciem - wyczuwa to, co poza rzeczywistością konsystencjalną. Dlatego też pozwala sobie na snucie o prawdach zakrytych dla świata fizycznego. Stwierdza, że życie to tylko „daleki odblask płomienia”. Owe przekonanie popycha mówiącego do poszukiwania źródła życia. I rzeczywiście je odnajduje. Jego źródłem okazuje się gloryfikowany, wręcz deifikowany ogień - możliwe, że dla poszukiwacza prawdy o świecie Absolut jest utożsamiany właśnie z tym żywiołem. Po tak znaczącym odkryciu czyni jednak pesymistyczne, przepełnione smutnym racjonalizmem, rozpoznanie z wykorzystaniem par zestawień - ogień płonie = człowiek rodzi się; ogień gaśnie = człowiek umiera. Życie człowieka, jak światło gwiazd, dobiegnie kiedyś końca.

Źródłem światła - poza Księżycem, Słońcem czy kamieniami szlachetny$\mathrm{mi}$ - są również gwiazdy:

42 Tytuł liryku bezsprzecznie nawiązuje do łacińskiej sentencji „sic transit gloria mundi”. W przekazie wiersza, traktującego o śmierci i przemijaniu, warto odnotować źródła słowa „trans" (za) i „transeo” (przechodzić). „Trans” sugeruje, że coś jest za nieprzekraczalną granicą (,trans rivum”). Co ciekawe, takie wyrazy jak „trans”, „transeo”, „transcendere” mają wspólny źródłosłów.

43 W. Korab-Brzozowski, Sic transit, [w:] tegoż, Utwory zebrane, s. 273. 
O, Sławo! blaskiem swym najczyściej

Zakwitasz właśnie w klęsk godzinie.

I gwiazdy płoną tym rzęsiściej,

Im głębsza noc na ziemie spłynie

A wszystko? - W biegu czasu ginie... ${ }^{44}$

Nie emitują one jednak światła byle jakiego, to światło ogniste - gwiazdy, jak pisze sam poeta, „płoną”. Podobnie słowa w poezji Korab-Brzozowskiego zyskują nowe jakości, stają się bytem naznaczonym ognistością. Ich blask jest czynnikiem wspierającym fenomen ,zakwitania” werbalnego medium. Ognisto-kwiatowa metafora rozkwitania słów przywodzi na myśl założenia fenomenologii percepcji Maurice'a Merleau-Ponty'ego, który przekonywał, że byty w zaskakujący sposób potrafią przenikać się, naznaczając wzajemnie cechami ${ }^{45}$. $\mathrm{Z}$ wspomnianym zjawiskiem mamy bezsprzecznie do czynienia w Przeciwieństwach, które to nie bez powodu poeta desygnuje takim właśnie tytułem.

Płonięcie firmamentu jest także wyróżnikiem innego wiersza poety, drugiego liryku z cyklu Węglem smutku i zgryzoty:

\section{Zachód wieczorny się pali}

I nie będzie księżyca i gwiazd na firmamencie:

Ogień Zachodu i zmierzchy,

W jakimś szalonym zamęcie,

Pokryją kirem drzew wierzchy -

I będą cyprysy;

Ubiorą w szkarłaty

Kwiaty -

I będą róże;

Spadną tumanem krwi, legną w popiele -

I będą maki;

I, dziwnym czarem ich -

Asfodele ${ }^{46}$.

44 Tenże, Przeciwieństwa, [w:] tegoż, Utwory zebrane, s. 217.

45 M. Merleau-Ponty, Cogito, [w:] tegoż, Fenomenologia percepcji, przeł. M. Kowalska, J. Migański, posł. J. Migański, Warszawa 2001, s. 387.

46 W. Korab-Brzozowski, Węglem smutku i zgryzoty II, [w:] tegoż, Utwory zebrane, s. 63. 
Nocny pejzaż ustępuje sile zachodzącego słońca, które nieustannie rządzi światem. Krajobraz nadchodzącej nocy, łączy się jednocześnie z barwą szkarłatu, konotującą żywioł ognia. Zaistnieniu fenomenów, składających się na wieczorny krajobraz, sprzyjają specjalne warunki: szkarłat płonącego słońca wpływa na barwy przedstawicieli tutejszej flory - cyprysy, róże, maki i asfodele naznaczone czerwienią ulegają metamorfozie. Róże i maki pod wpływem hiperbolizacji stają się jeszcze bardziej czerwone, zaś cyprysy i asfodele (kwiaty symboliki funeralnej) przyjmują nowe cechy - płoną. Ogień funkcjonuje w liryku jako twórca nowej rzeczywistości, drogowskaz, jako żywioł, dokonujący transgresji w rzeczywistości, a zatem byt aktywnie wpływający na wspomniane fenomeny.

We wspominanym już cyklu Węglem smutku i zgryzoty również pojawia się motyw Słowa. Niemniej sytuacja liryczna wiersza okazuje się diametralnie różna od omówionej w Przeciwieństwach. Wykorzystuje ona jeden z bardziej intrygujących motywów biblijnych - chrztu ogniem. Głos, któremu pozwala mówić podmiot liryczny, oznajmia:

\author{
„Iżeś ty jeszcze moc miał rzeknąć sobie: \\ Nikczemnym jest", Łazarzu! wyprostuj swe kroki \\ I idź! Oto rozedrę Słowem Moim mroki \\ I ich ciężkie łachmany, co skryły twą głowę. \\ I objawię ci wielkie strumienie ogniowe, \\ Abyś się w nich wykąpał i wyszedł bez zmazy \\ Na puszczę, gdzie pilnym bądź na Znak i Rozkazy ${ }^{47}$.
}

Pewne fragmentu Starego i Nowego Testamentu (Mal. 3,2-3; Łuk. 9,23; Ef. 5,27) głoszą, że przejście próby ognia - kształtującego serce, wytapiającego słabości i kreującego wybranych przez Mesjasza - jest aspektem koniecznym na drodze poznania i kroczenia ścieżką oświecenia.

Mówiąc o funkcjonowaniu ognia w poezji autora Domus aurea, warto przyjrzeć się lirykowi, który poeta napisał wspólnie z bratem Stanisławem, tu również dostrzeżemy wkraczanie na ścieżkę mądrości i poznania: 
Hefajstos, boski kowal, kruszcu złom z ciemnicy

Gór przepastnych, gdzie wiecznie panuje noc głucha,

Dobywszy, z trudem niesie, sapie, chwyta ducha,

Aż wreszcie na ziem ciska w głębi swej kuźnicy,

I skinął: na znak jego czujni robotnicy,

Cyklopi, ogień niecą: już żar krwawy bucha;

Więc bryłę weń wrzucają, aż skier zawierucha

Gardzielą Etny strzela w dymów nawałnicy.

On tymczasem młot chwyta w dłoń i z siłą turzą

Kuje metal jęczący, a echem mu wtórzą

Uderzenia Cyklopów - olbrzymich wśród żaru.

A coraz bardziej nagli młota swego razy,

Albowiem ujrzał, mocą swej twórczej ekstazy,

Na tarczy Achillesa Gród w łunach pożaru48.

Anna Wydrycka, analizując sytuację przedstawioną w Tarczy Achillesa, konstatowała: „We wszystkich sonetach wyeksponowane zostały czynności, nie są one statycznym opisem jakiegoś przedmiotu, lecz opisem dynamicznych działań" 49 . Z rozpoznaniem tym należy się bezwzględnie zgodzić. Wypada jednak wyeksponować to, czego do tej pory nie wyakcentowano zbyt dokładnie właśnie funkcji ognia. Nietrudno dostrzec, że dynamiczność działań bohaterów wiersza zmienia się wraz z intensywnością ognistego medium. Rozpoczęcie prac sygnalizuje obecność kuźni, miejsca, w którym o dzianiu decyduje ogień. Ów żywioł jest dopiero rozniecany, zatem prace nad tarczą są w początkowej fazie. Wraz z upływem czasu prace nad militarnym dziełem sztuki posuwają się do przodu, a zatem i przestrzeń stopniowo ulega zmianie, gdyż jest z nim nierozerwalnie zespolona. Zaobserwować można konkretne zmiany w fizyczności ognia, gdy poeta mówi metaforycznie o wzniecaniu żaru, zawierusze iskier,

48 W. Korab-Brzozowski, Tarcza Achillesa, [w:] tegoż, Utwory zebrane, s. 54.

49 A. Wydrycka, ,Tryumfy” Stanistawa i Wincentego Korab Brzozowskich w kontekście tradycji antycznej, [w:] tejże, Rzady poezji, Młodopolska liryka - studia i interpretacje, Białystok 2016, s. 146. 
gardzieli Etny i wielkiej łunie pożaru. Intensywność ognia wpływa na piękno rodzącego się w płomieniach przedmiotu. Ale to nie jedyna funkcja (twórcza) ognia. Zamykająca dzieło strofa konotuje jego profetyczne zdolności. Ogień jest medium, swoistym lustrem w przyszłość, pełni zatem funkcję wizyjną, jest łącznikiem między światem teraźniejszym a przyszłością.

Finalizując analizy, należy wyakcentować, że niemalże cały dorobek Korab-Brzozowskiego (wyjątek stanowi cykl Spotkanie) przepełnia żywioł ognia. Co ważne, mimo znacznej ilości utworów, właściwie brak w nich powtórzeń tematycznych. Przykładowo w opisach źródeł obyczajów i kultury antycznej (Ojcu swojemu synowie Stanisław i Wincenty, Tarcza Achillesa, Stonie) wyzyskana została wielowiekowa tradycja afirmująca różne aspekty zwycięstwa. Jedynymi motywami, które poeta powielał, były te dotyczące personifikacji sztuki oraz roli poety w świecie i życiu społeczeństwa. Poza Inwokacja do muz czy Wróżbą, warty wyeksponowania wydaje się liryk Wezwanie, w którym to poeta przejmująco peroruje do przyjaciół pióra: „Poeci - czyści, jak płomień straszliwi" 50 . Głos ujawniający się w Wezwaniu ma świadomość wartości i potęgi twórczej aktywności. Poeta dysponuje niemniej potężnym narzędziem, co ogień. Performatywność słowa nie ustępuje w niczym niszczycielskiej sile trawiącego żywiołu.

\section{Podsumowanie}

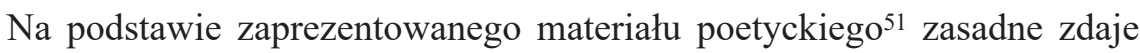
się przekonanie, że autor Epopei wyposaża ogień w wartości przypisywane tradycyjnie wszystkim innym żywiołom. Ogień buduje, chłodzi, ożywia, scala - jest fundamentem życia. Świat Brzozowskiego - w zgodzie z zasadą coincidentia oppositorum - tonie w ogniu, który oczyszcza, przemienia, dokonuje transformacji tego, co fizyczne, i tego, co duchowe ${ }^{52}$. Ogień jako źródło światła to u Brzozowskiego przede wszystkim Słońce, ale też gwiazdy i Księżyc

50 W. Korab-Brzozowski, Wezwanie, [w:] tegoż, Utwory zebrane, s. 281.

51 Oczywiście, wystąpień ognia w poezji Korab-Brzozowskiego jest znacznie więcej, niemniej wyeksponowane zostały takie egzemplifikacje, które umożliwiły jak najdokładniejsze oddanie całościowego charakteru żywiołu w tej poezji.

52 Por. J. Słowacki, Mindowe, akt I: 26-30: „Ja - spłonę na stosie/ Mnie modrzew cichym szumem do snu ukołysze,/ Jeszcze usiędzie sokół na martwym ramieniu,/ Nastrzępi pióra chartów zaskowycze sfora,/ Ani mię ciasna ziemi uwięzi zapora,/ Ja z pieśnią Wajdeloty ulecę w płomieniu". 
czy kamienie szlachetne. Poeta bezsprzecznie sytuuje ogień w funkcji najważniejszego z żywiołów, niekiedy nawet go deifikuje. Jeśli przyjąć za Gastonem Bachelardem, że żywioły indywidualizują typy wyobraźni, to wyobraźnię poetycką Korab-Brzozowskiego bez wątpienia projektuje żywioł ognia. Oniryczny temperament poety-marzyciela funduje obrazy poetyckie świetliste, żarliwe, migotliwie chwiejne znaczeniowo, i czyni to chyba na wzór ognia, który przejawia właśnie takie cechy. $\mathrm{W}$ ten sposób poeta niewątpliwie podnosi rangę swej poetyckiej spuścizny.

\section{Bibliografia}

Bachelard G, Poetyka marzenia, przeł. i oprac. L. Brogowski, Gdańsk 1998.

Bachelard G., Filozofia, która mówi nie, przeł. J. Budzyk, Gdańsk 2000.

Bachelard G., Płomień świecy, przeł. J. Rogoziński, Gdańsk 1996.

Bachelard G., Wyobraźnia poetycka, przeł. H. Chudak, A. Tatarkiewicz, Warszawa 1975.

Borek B., „Próżne nam były Kasandry wołania”. O wybranych inspiracjach antykiem w twórczości Wincentego Korab-Brzozowskiego, „Studia Ełckie” 2019, nr 2 , s. 275-292.

Eliade M., Kowale i alchemicy, przeł. A. Leder, Warszawa 1993.

Filar D., Poetyckie kreacje cielesności w wybranych utworach poezji współczesnej, [w:] Kreowanie świata w tekstach, red. A. M. Lewicki, R. Tokarski, Lublin 1995. Frontczak J., Poszukiwanie paradygmatu, „Sztuka i Filozofia” 1996, nr 11.

Głowiński M., Ten śmieszny Prometeusz, [w:] tegoż, Mity przebrane. Dionizos, Narcyz, Prometeusz, Marchołt, Labirynt, Kraków 1990.

Kerényi K., Prometeusz, [w:] tegoż, Misteria Kabirów; Prometeusz, przeł. I. Kania, Warszawa 2000.

Kirk G. S., Raven J. E., Schofield M., Filozofia przedsokratejska, przeł. J. Lang, Warszawa, Poznań 1999.

Korab-Brzozowski W., I ciepły jeszcze, purpurowy sznur, [w:] tegoż, Utwory zebrane, oprac. M. Stala, Kraków 1980.

Książyk Ł., Maski Prometeusza, [w:] Modernistyczne źródła dwudziestowieczności, red. M. Dąbrowski, A. Z. Makowiecki, Warszawa 2003. 
Kurkiewicz M., Bohaterowie antycznych mitów w poezji twórców Młodej Polski, [w:] Ateny. Rzym. Bizancjum. Mity śródziemnomorza w kulturze XIX i XX wieku, red. J. Ławski, K. Korotkich, Białystok 2008.

Kwiatkowski J., Od katastrofizmu solarnego do synów słońca, [w:] Młodopolski świat wyobraźni, red. M. Podraza-Kwiatkowska, Kraków 1977, s. 231-325.

Ławski J., Wyobraźnia lucyferyczna. Szkice o poemacie Tadeusza Micińskiego "Niedokonany. Kuszenie Chrystusa Pana na pustyni", Białystok 1995.

Merleau-Ponty M., Cogito, [w:] tegoż, Fenomenologia percepcji, przeł. M. Kowalska, J. Migański, posł. J. Migański, Warszawa 2001.

Michał Anioł, Sonet 59, [w:] tegoż, Poezje, przeł., wstęp i przypisy L. Staff, Warszawa-Kraków 1922.

Myszor W., Orygenes jako systematyk, [w:] Orygenes, O zasadach, przeł. S. Kalinkowski, Warszawa 1979.

Pietras H., Początki teologii kościoła, Kraków 2007.

Popczyk M., Ogień, [w:] Estetyka czterech żywiołów, red. K. Wilkoszewska, Kraków 2002

Przybysławski A., Coincidentia oppositorum, Gdańsk 2004.

Reale G., Pitagoreizm, [w:] tegoż, Historia filozofii starożytnej, t. 1, przeł. E. I. Zieliński, Lublin 2005.

Rowiński C., Prometeusz, [w:] Mit, człowiek, literatura, wstęp S. Stabryła, Warszawa 1992.

Schuré E., Wielcy wtajemniczeni. Zarys tajemniczych dziejów religii, przeł. W. Nidecka, Warszawa 1926.

Słownik myśli filozoficznej, red. M. Kuziak, S. Rzepczyński i in., Bielsko-Biała 2004.

Szczerba W., Kosmiczna koncepcja wiecznego powrotu w filozofii starej Stoi, „Theologica Wratislaviensia" 2007, t. 2.

Trznadel J., Wincenty Korab-Brzozowski, [w:] Literatura okresu Młodej Polski, t. 1, red. K. Wyka, A. Hutnikiewicz, M. Puchalska, Warszawa 1968, s. 531-547.

Wydrycka A., "Tryumfy" Stanisława i Wincentego Korab Brzozowskich w kontekście tradycji antycznej, [w:] tejże, Rządy poezji. Młodopolska liryka - studia i interpretacje, Białystok 2016. 